\title{
СТОМА И.О. МИКРОБИОМ ЧЕЛОВЕКА / И.О. СТОМА, И.А. КАРПОВ. - МИНСК: ДОКТОР ДИЗАЙН, 2018. - 122 с.
}

\begin{abstract}
Давно відомо, що мікроорганізми та людський організм перебувають у тісному взаємозв'язку. Найновіші результати молекулярно-генетичних досліджень мікробіома людини підтвердили його необхідність як обов'язкову умову життєдіяльності нашого організму. Однак сучасні досягнення в цій ділянці знань залишаються маловідомими для широкого кола лікарів.
\end{abstract}

Основу рецензованої монографії склали дослідження, виконані в лабораторії «Eric Pamer Lab» Меморіального онкологічного центру ім. Слоуна-Кеттерінга, що в Нью-Йорку (США), з якою співпрацюють автори книжки - білоруські колеги. Саме в названій американській лабораторії вдалося створити найбільшу колекцію людських мікробіомів, детальна характеристика яких дасть змогу краще вияснити роль мікробів у підтриманні здоров'я людини та в розвитку різних хвороб.

Головні дослідження мікробіома ґрунтуються на визначенні варіабельних ділянок високо консервативного гена, що кодує 16s-субодиницю рибосомальної РHК (16s pPHK) мікроорганізмів. Цей ген мають усі бактерії, але його немає в ссавців. Він містить дев ять гіперваріабельних ділянок $\left(V_{1}-V_{9}\right)$, які можна порівнювати з еталонними геномами й таким чином ідентифрікувати вид конкретної бактерії. У зв'язку з цим, автори монографії твердять, що звичайні культуральні методи не придатні для дослідження мікробіоти людини та застерігають від використання термінів «дисбактеріоз» і «дисбіоз», встановлених завдяки посіву калу, слини, виділень з піхви на штучні поживні середовища.

Стисло описано структуру та захисні фрункції мікробіома кишок, подано його вплив на фрармакокінетику та фрармакодинаміку ліків. Узагальнено відомості про дію різних антибіотиків і протипухлинних препаратів на мікробіом.

У наступних розділах наведено характеристику мікробіоти кишечнику в осіб з імуносупресією, інфекційними захворюваннями (C. difficile-асоційована інфекція, гострі респіраторні інсрекції, пневмонія, ботулізм екзо- та ендогенного походження, інфекції сечовидільної системи).
Особливу увагу приділено трансплантації фрекальної мікробіоти, зокрема для лікування C. difficile-асоційованої інфекції, яка активно впроваджується при тяжких запальних захворюваннях кишечнику. На порядок денний висунуто ідею заміни трансплантації фрекальної мікробіоти капсулами із захисними мікроорганізмами. Наведено дані про зміни мікробіома при неінфекційних хворобах - метаболічному синдромі, захворюваннях печінки, бронхіальній астмі, атопічному дерматиті, взаємозв'язок мікробіома кишечнику з центральною нервовою системою.

Основні положення монографрії проілюстровані 31 рисунком. У бібліограсрічному списку наведено 512 джерел сучасної наукової літератури.

Можна стверджувати, що монографрія «Мікробіом людини» буде корисна для лікарів-клініцистів, а також імунологів, мікробіологів, фрармакологів та інших профрільних науковців.

\section{Відомості про автора:}

Андрейчин Михайло Антонович - академік НАМНУ, професор, д. мед. н., завідувач кафедри інфрекційних хвороб з епідеміологією, шкірними і венеричними хворобами Тернопільського державного медичного університету iм. І.Я. Горбачевського; andreychyn@tdmu.edu.ua

\section{Information about author:}

Andreychyn M.A. - academician of the NAMS of Ukraine, Doctor of Medicine, Head of the Infectious Diseases and Epidemiology, Skin and Venereal Illnesses Department of I. Horbachevsky Ternopil State Medical University; andreychyn@ tdmu.edu.ua

Конфрлікт інтересів: немає.

Author has no conflict of interest to declare.

Отримано 28.02.2019 р. 